\title{
Correction to: An Identification Guide for Metallurgical Sites in Tanzania
}

\author{
Edwinus Chrisantus Lyaya
}

Published online: 14 May 2019

(C) Springer Science+Business Media, LLC, part of Springer Nature 2019

\section{Correction to: Afr Archaeol Rev \\ https://doi.org/10.1007/s10437-019-09334-0}

In the original online first publication of this article, the first sentence of the conclusion was erroneously written as: This work has shown that each of the three stages. The correct sentence is: This work has shown that each of the three stages of iron production has distinct characteristics.

The original article has been corrected.

Publisher's Note Springer Nature remains neutral with regard to jurisdictional claims in published maps and institutional affiliations.

The online version of the original article can be found at https://doi.org/10.1007/s10437-019-09334-0

E. C. Lyaya $(\bowtie)$

Department of Archaeology and Heritage, University of Dar es Salaam, P.O. Box 35050, Dar es Salaam, Tanzania e-mail: edwinusl@yahoo.com 